Journal of Social Sciences 5(3): 239-243, 2009

ISSN 1549-3652

(c) 2009 Science Publications

\title{
Development of Socioscientific Issues-Based Teaching for Preservice Science Teachers
}

\author{
Prasart Nuangchalerm \\ Department of Curriculum and Instruction, Faculty of Education, \\ Mahasarakham University, Mahasarakham 44000 Thailand
}

\begin{abstract}
Problem statement: In the context of science education reform in Thailand, we need to prepare science teachers who can face science and social issues controversial; teachers can response the question socioscientific issues and let their students to meet the goal of science education. This study investigated the conception leading preservice science teachers approaching socioscientific issues-based teaching. The activities in classroom emphasized on peer discussion about science and social reflection, nature of science, making decision based on moral and ethics was employed. Approach: The purpose of this study was to develop preservice science teachers which promote the introduction of socioscientific issues in the classroom. One hundred and one preservice science teachers were asked about conception of socioscientific issues-based teaching. Based on reality of pedagogical aspect, they need to know nature of science and conception about how to incorporate science and social issues into classroom. Result: Most of them showed their beliefs for socioscientific issues-based teaching in terms of ways to promote nature of science. The ideas for teaching need awareness of science and society, scientific values, personal experiences, moral and ethics in science and social judgment. Also, this study showed that preservice science teacher express their satisfaction on the activities at high level. Conclusion/recommendations: The results recommend the socioscientific issues-based teaching for curriculum development and program for gaining preservice teachers to aware their role in science classroom.
\end{abstract}

Key words: Preservice science teacher, socioscientific issues, SSI, nature of science, conception, social judgment, satisfaction, scientific literacy

\section{INTRODUCTION}

The phrase "scientific literacy" is addressed the context of science and its role in the changing world. This study advances a conception of scientific literacy which involves the negotiation of socioscientific issues. It requires ability to make informed decisions regarding socioscientific issues ${ }^{[1]}$. Socioscientific issues are moral and ethical implications; therefore, the promotion of scientific literacy requires curricular attention to the moral and ethical implications of socioscientific issues. Scientific literacy is important for every student. Most students will not become professional scientists. They need to be able to use scientific processes and habits of mind to solve problems faced in everyday life and to confront issues that involve science and make informed decisions ${ }^{[2]}$. Student must be capable of considering and resolving criteria about controversial science and social issues.

The socioscientific issues offer way to explore the nature of science, bridge student and scientific literacy, interdependence of science and society movement and democratizing science in society ${ }^{[3,4]}$. Students decisionmaking on socioscientific issues and evaluation of contradictory scientific information are complex, they are led to emphasize personal experiences or values ${ }^{[5]}$. Sadler ${ }^{[6]}$ suggested that "curricula pertaining to the social, tentative and empirical aspects of science would be particularly useful for students as they confront socioscientific issues." Students' interpretation and evaluation of contradictory were influenced by their personal opinions and their scientific knowledge, but also on assumptions on the nature of science, how data are interpreted and the interaction of science and society.

Preservice science teacher is a key element to promote nature of science for students and also develop ethical skills to faced new knowledge or product of science in societal participation. Preservice science teacher need to develop their own conception about socioscientific issues-based teaching helping their students meets real science. As responsibility, they have to ensures explicitly discusses with students how features of nature of science relate to features of science 
classroom inquiry. Preservice science teachers will have thinking about how to apply this knowledge to their science teaching. This study aims to develop preservice science teachers which promote the introduction of socioscientific issues in the classroom. Making conception how to incorporate science and social issues into classroom are employed.

\section{MATERIALS AND METHODS}

Sample: In the second semester, academic year 2008, One hundred and one of preservice science teachers who enrolled course 0506408 Seminar and Developing Teachers' Experiences.

Research tools: This research was employed two types of research tools; questionnaire about preservice teachers' conception on socioscientific issues-based teaching, is try to interview and explain what they understand and questionnaire asking preservice science teachers' satisfaction on learning activates which promote socioscientific issues-based teaching.

Procedure: In the research, conduct learning activities to promote socioscientific issues-based teaching, observe classroom during a lesson and interview methods have been used in the scope of qualitative approach.

Researcher clarified a purpose of this research for data collective cooperation with group of sample. During 30 hours socioscientific issues-based teaching, researcher let preservice science teachers' understanding nature of science and scientific literacy through this approach. Four criteria were asked 101 preservice science teachers about ideas and concepts of socioscientific issues-based teaching. The criteria were asked which relevant to personal knowledge. Data were compiled in separate folders for each participant. It was used to conceptualize the data. Some of each case was developed after reading and rereading the data.

Then, preservice science teachers response their satisfaction to this approach, the data have been defined and interpreted. The level of satisfaction to be consider with Likert's five-point rating scale. Each respondent is asked to rate each item on some response scale. They could rate each item on a 1-5 response scale where; 1 = strongly disagree, $2=$ disagree, 3 = undecided, $4=$ agree and $5=$ strongly agree. Data were analyzed by mean and standard deviation.

Finally, the researcher analyzed collected data by using a computer program, checked the completeness of the data and then obtained data from responses to the questionnaire. Data were recorded; statistic values were calculated and interpreted by using the criteria as below:

$\begin{array}{ll}\text { Mean } & \text { Interpretation } \\ 4.50-5.50 & \text { Highest } \\ 3.50-4.49 & \text { High } \\ 2.50-3.49 & \text { Medium } \\ 1.50-2.49 & \text { Low } \\ 1.00-1.49 & \text { Lowest }\end{array}$

\section{RESULTS}

Socioscientific issues-based teaching concept: Preservice science teachers reflect their own personal knowledge in terms of socioscientific issues based teaching. Most of them raised concept and shared ideas to this approach in many ways. They believed that science and social issues are recently debated and it has been developed, concerning science and citizenship and the meaning of scientific literacy for classroom teaching. Efforts for the development of preservice teachers' experience on scientific literacy towards the goal promoting preservice science teachers' scientific literacy are generalized. They also proposed ideas relevant to goal of science education, nature of science, concerns, values and ethics:

- "Teaching science through socioscientific issuesbased teaching, we have awareness on moral and ethics during science hours to sustain between knowledge and ethics in congruently" Preeyanut

- "Science teaching, socioscientific issues-based teaching is needed to integrate content knowledge into students' every day life." Juthamanee

- "Socioscientific issues-based teaching emphasizes on ethics in science, leads reasoning and nature of reality into ethics" Pichai

However, learning activities based on socioscientific-based teaching is challenge science curriculum in Thailand. We need to prepare science teacher who have scientific literate. Findings indicated that science classroom climate can stimulate student aware science and social issues, nature of science and scientific literacy. The learning process calls for teacher awakes searching skills, collect and analyze socioscientific issues, allow students to learn new experiences through reliable scientific articles, discuss science and social issues with peers:

- "Socioscientific issues-based teaching need students give some examples and then allow them to discuss relationship between scientific reasoning and ethical reasoning" Khambhoon 
Table 1: Preservice science teachers' satisfaction on socioscientific issues-based teaching

\begin{tabular}{|c|c|c|c|}
\hline Item & $\overline{\mathrm{X}}$ & S.D. & Level of response \\
\hline I like to search scientific information from various kind of tools & 4.41 & 0.58 & High \\
\hline I happy to read articles in many ways & 4.00 & 0.59 & High \\
\hline I prefer to present and discuss articles are broadest & 4.28 & 0.68 & High \\
\hline I feel that this activity make me more confidently on teaching practicum & 4.12 & 0.65 & High \\
\hline This activity make me more confidently on conducting classroom action research & 4.05 & 0.69 & High \\
\hline I think this activity help me learn how to make empathy with others & 4.23 & 0.62 & High \\
\hline This activity help me know how to prepare science classroom & 4.13 & 0.67 & High \\
\hline I prefer, this activity help me gaining learning innovation & 4.32 & 0.64 & High \\
\hline This study reinforce me to seek new instructional design & 4.32 & 0.64 & High \\
\hline The activity make me proud in teaching profession & 4.49 & 0.63 & High \\
\hline I think, this activity help me to evaluate academic values & 4.31 & 0.62 & High \\
\hline This activity promote me in terms of academic ethics & 4.40 & 0.64 & High \\
\hline I prefer this activity promote my creative thinking & 4.26 & 0.60 & High \\
\hline I prefer this activity promote my critical thinking & 4.22 & 0.57 & High \\
\hline I prefer this activity promote my analytical thinking & 4.30 & 0.63 & High \\
\hline I think this activity help me to construct knowledge & 4.47 & 0.65 & High \\
\hline I like to have peer discussion & 4.48 & 0.65 & High \\
\hline This activity promote my emotional maturation & 4.17 & 0.65 & High \\
\hline This activity promote my instructional media & 4.32 & 0.64 & High \\
\hline This activity allow me to meet professional presentation & 4.44 & 0.57 & High \\
\hline I prefer this activity promote my reasoning skills & 4.35 & 0.55 & High \\
\hline I prefer this activity set self assessment & 4.21 & 0.69 & High \\
\hline This activity make me have environmental awareness & 4.26 & 0.71 & High \\
\hline This activity promote educational research methodology & 4.39 & 0.62 & High \\
\hline I feel this activity can help me to have readiness on teaching professional experiences & 4.56 & 0.60 & Highest \\
\hline Total & 4.30 & 0.63 & High \\
\hline
\end{tabular}

- "It needs more change in science classroom climate by integrating science and social issues, conflict simulation, peer discussion and also stimulating them by attractive media for learning" Jareebhorn

Socioscientific issues-based teaching can make a connection among goal of science education, student needs and fulfill them to be full man. i.e., higher order thinking, discussion skills, scientific argumentation, inquiry-based learning and understanding the nature of science:

- "Socioscientific issues is very useful for students to awake their thinking ability and decision-making skills based on evidences and nature of science" Juthamanee

- "Socioscientific issues-based teaching can gain students' scientific reasoning skills and making scientific argumentation" Pacharaya

- "Socioscientific issues-based teaching stimulate students aware moral, ethics, concerns, values and social participation at all level" Preeyanut

Socioscientific issues-based teaching leads preservice science teachers to nature of science and scientific literacy. The results can be introduced into school science, prepared preservice science teachers before professional experiences occur.
Satisfaction with Learning on socioscientific issuesbased teaching: Respondents were asked to rate their satisfaction with various aspects of their feelings. Levels of satisfaction were recorded across a range of indicators. Respondents were most satisfied with the level of learning activities through socioscientific issues-based teaching $(\bar{X}=4.30)$. Only item No. 25 they feel that socioscientific issues-based teaching can help them to have readiness on teaching professional experiences at highest level $(\overline{\mathrm{X}}=4.56)$ (Table 1).

\section{DISCUSSION}

The ideational teaching science need to response scientific literacy and fulfill nature of science that deals with authentic socioscientific issues related to the way of life. The unit aimed to enhance active participation of the learners and encourage higher order thinking in class by applying teaching methods that reduce the unfamiliarity felt by students. This was expected through an explicit use of a variety of teaching and assessment-for-learning methods, suitable for Science for All students. In order to address the main learning objectives, we monitored students' performances in tasks that required the higher order thinking skills of argumentation and value judgment, which are central constituents of decision-making processes ${ }^{[7,8]}$. 
Preservice science teachers reflect their own personal knowledge in terms of socioscientific issuesbased teaching. They believed that science and social issues is recent debate and it has been developed, concerning science and citizenship and the meaning of scientific literacy for classroom teaching ${ }^{[9]}$. If preservice science teachers understand nature of science in this context, it will help them to appreciate that one strength of science lies in its subjectivity. Because science influences social, cultural and personal frameworks and varied perspectives brought to science enable breakthroughs to occur and scientific progress. It can be discussed that teaching preparation for them should be understandable through socioscientific issues-based teaching. Thus, they know and understand the entire concept that can help them to consider. Although instructional preparation needs more inquires, learn to be a master teacher is not easy to do than those they think ${ }^{[10]}$.

Socioscientific issues-based teaching can make a connection between goal of science education and student needs and fulfill them to be full man in such higher order thinking, discussion skills, scientific argumentation, inquiry-based learning and understanding the nature of science. It is challenge science curriculum in Thailand. We need to prepare science teacher who have scientific literate. Findings indicated that science classroom climate can stimulate student aware science and social issues, nature of science and scientific literacy. This approach can be introduced into science curriculum and program of study for preservice science teachers before they have professional experiences.

\section{CONCLUSION}

Research reported here involves, is clear that teaching controversial social issues in science contexts raises difficult problems for preservice science teacher in managing discussion of socio-scientific issues. Several themes are analyzed of the lesson transcripts involving classroom exchange and teacher interviews. These are 'control of discussion', 'teacher-student difference in belief systems' and 'distinction in classroom discourse between science and ethics'. Ethical aspects would appear to have an effect on the teacher's authority. Finding provides a broader description of the cognitive and affective domains that a teacher has to contend with in a discussion of ethical issues in a science context and implications for the professional development of science teachers. The study can be described that this approach can make a bridging between science teacher preparation program and goal of science education.

\section{ACKNOWLEDGEMENT}

I would like to express my sincere appreciation to the Faculty of Education, Mahasarakham University for financial support.

\section{REFERENCES}

1. Kolst $\varnothing$, S.D., 2001. Scientific literacy for citizenship: Tools for dealing with the science dimension of controversial socioscientific issues. Sci. $\quad$ Educ., $\quad$ 85: 291-310. http://cat.inist.fr/?aModele $=$ afficheN\&cpsidt $=1157$ 712

2. Sadler, T., 2004. Moral and ethical dimensions of socioscientific decision-making as integral components of scientific literacy. Sci. Educ., 13: 39-48. http://www.highbeam.com/doc/1P3866075171.html

3. Driver, R., P. Newton and J. Osborne, 2000. Establishing the norms of scientific argumentation in classrooms. Sci. Educ., 84: 287-312. http://cat.inist.fr/?aModele $=$ afficheN\&cpsidt $=1546$ 198

4. Sadler, T.D. and D.L. Zeidler, 2005. Patterns of informal reasoning in the context of socioscientific decision making. J. Res. Sci. Teach., 42: 112-138. http://cat.inist.fr $/$ ?aModele $=$ afficheN\&cpsidt $=1656$ 0790

5. Fensham, P.J., 2002. De nouveaux guides pour l'alphabétisation scientifique. Can. Sci. Math. Technol. Educ., 2: 133-150.

6. Sadler, T.D., 2004 Informal reasoning regarding socioscientific issues: A critical review of research. J. Res. Sci. Teach., 41: 513-536. http://cat.inist.fr/?aModele $=$ afficheN\&cpsidt $=1600$ 5916

7. Zeidler, D.L., K.A. Walker, W.A. Ackett and M.L. Simmons, 2002. Tangled up in views: Beliefs in the nature of science and responses to socioscientific dilemmas. Sci. Educ., 86: 343-367. http://cat.inist.fr/?aModele $=$ afficheN\&cpsidt $=1421$ 2677

8. Zeidler, D.L., T.D. Sadler, M.L. Simmons and E.V. Howes, 2005. Beyond STS: A Researchbased framework for socioscientific issues education. Sci. Educ., 89: 357-377. http://cat.inist.fr/?aModele $=$ afficheN $\&$ cpsidt $=1678$ 8767 
9. Michaels, E. and R.L. Bell, 2003. The nature of science: Perceptual and frameworks emphasizing a more balanced approach to science instruction. Sci. Teachers, 70: 36-39. http://www.eric.ed.gov/ERICWebPortal/custom/po rtlets/recordDetails/detailmini.jsp?_nfpb=true\&_\& ERICExtSearch_SearchValue_0=EJ789688\&ERIC ExtSearch_SearchType_0=no\&accno=EJ789688
10. Nuangchalerm, P., 2009. Implementing professional experiences to prepare preservice science teachers. Soc. Sci., 4: 388-391. http://papers.ssrn.com/sol3/papers.cfm?abstract_id $=1346186$ 